\title{
Markers of Acute Stress in Pigs
}

\author{
K. BREINEKOVÁ ${ }^{1}$, M. SVOBODA ${ }^{3}$, M. SMUTNÁ ${ }^{2}$, L. VORLOVÁ $^{1}$ \\ ${ }^{I}$ Department of Milk Hygiene and Technology, ${ }^{2}$ Department of Biochemistry, Chemistry and \\ Biophysics, Faculty of Veterinary Hygiene and Ecology, University of Veterinary \\ and Pharmaceutical Sciences Brno and ${ }^{3}$ Clinic of Pig Diseases, Faculty of Veterinary Medicine, \\ University of Veterinary and Pharmaceutical Sciences Brno, Czech Republic
}

Received January 9, 2006

Accepted March 29, 2006

On-line available June 22, 2006

\begin{abstract}
Summary
This study explores the biological validation of markers of acute stress in pigs subjected to transportation for slaughter. The stress markers selected for monitoring were neopterin and cortisol. Their levels in pig serum were measured for two porcine stress syndrome genotypes, $\mathrm{NN}$ and $\mathrm{Nn}$, after a 30-min transport to a slaughterhouse. Blood samples were withdrawn before transport (control group) and immediately after the animals' arrival (experimental group). The values of neopterin and cortisol measured before the transport were $5.60 \pm 1.65 \mathrm{nmol} / 1$ and $273.54 \pm 66.17 \mathrm{nmol} / 1$ respectively. After the transfer, the concentration of cortisol rose significantly compared to the control $(355.69 \pm 85.13 \mathrm{nmol} / \mathrm{l}$, $\mathrm{p}<0.01)$. Neopterin concentrations in the serum $(8.25 \pm 1.60 \mathrm{nmol} / \mathrm{l})$ were also significantly higher $(\mathrm{p}<0.01)$ after transportation. The elevated concentrations of both analytes were found to be independent of the genotype. These results document the stimulation of the endocrine system and the immune system that develops in animals undergoing transportation for slaughter.
\end{abstract}

\section{Key words}

Neopterin $\bullet$ Cortisol $\bullet$ Transport $\bullet$ Pig $\bullet$ Halothane gene

\section{Introduction}

In general, animals perceive any unusual manipulation, including transportation, as stressful, and it may ultimately prove to have a negative influence on animal welfare (von Borell 2001). The main stress factors, which affect the animals in the process of transportation, are noise, vibration, hunger and thirst on long trips, temperature and other psychic and physical stimuli. Reaction to stress involves activation of an extensive network encompassing the central nervous system as well as endocrine and immune responses. The consequence of stress-activated sympathetic nervous reaction is the formation of numerous active biomolecules such as ACTH, catecholamines and glucocorticoids (von Borell 2001). These substances are essential components of adaptation to stress; they affect the immune system of the organism (Moynihan 2003) and can be utilized as markers of stress situations (Möstl and Palme 2002).

During a stress reaction a whole spectrum of active substances is being generated in the course of an immune response, one of them being neopterin. Neopterin (D-erythro-6-trihydroxypropyl-pterin) belongs 
to the category of substances with heterocyclic structure (pyrazino-[2,3-D]-pyrimidin), which occur naturally in body fluids in an oxidized, as well as, a reduced form. Besides the pteridines, riboflavin and folic acid, which are important vitamins, mammals are capable of synthesizing other pteridines, such as neopterin, biopterin and oncopterin (Daňová 1998). Neopterin is produced in the organism by monocytes/macrophags, after having been stimulated by the cytokine interferon- $\gamma$ (INF- $\gamma$ ), which is released by T-lymphocytes and natural killer (NK) cells (Berdowska and Zwirska-Korczala 2001, Widner et al. 2002a, Hoffman et al. 2003). Important costimulants are tumor necrosis factor- $\alpha$ (TNF- $\alpha)$ and endotoxins (Hoffmann et al. 2003, Mitaka 2005). Neopterin is excreted from the body in an unchanged form by the kidneys (Fuchs and Wachter 1998). Although the information about the presence of neopterin and other pterine compounds such as biopterin, xanthopterin and oncopterin, has been available in the literature for some time, their biological significance is still unclear. Clinical studies in humans suggest that neopterin is a good indicator of cellular immunity activation. Higher neopterin concentrations were observed in connection with bacterial and viral diseases as well as inflammatory reactions (Vrecko et al. 1997, Widner et al. 2002b, Wirleitner et al. 2005). Neopterin function has also been the subject of many in vitro studies, which point to its impact on oxidation status due to neopterin prooxidative activity (Weiss et al. 1993, Baier-Bitterlich et al. 1995, Werner-Felmayer et al. 1995, Oettl et al. 1999, Schobersberger et al. 1996, Razumovitch et al. 2003). However, few studies deal with the issues surrounding the role of neopterin in animals other than primates. For example, an increased production of neopterin was noted by Myers et al. (2003) in pigs that had been given a dose of lipopolysacharide (E. coli O55:B5). Furthermore, neopterin does not reflect only the INF- $\gamma$ activity but complex immune reaction, which may include other cytokines, such as TNF- $\alpha$ and INF- $\alpha$ (Fuchs and Wachter 1998).

Malignant hyperthermia syndrome is an acute reaction to environmental disturbance (e.g. transport, high ambient temperature, mixing of pigs, noise) and it is caused by mutation of the ryanodine receptor on sarcoplasmatic reticulum. The clinical syndrome includes muscle rigidity, hypercapnia, tachycardia and myoglobinuria as result of increased carbon dioxide production, oxygen consumption and muscle membrane breakdown (Wappler 2001).
The objective of our work was to evaluate the impact of a short, stress-inducing transport on the porcine immune reaction and endocrine system. As markers, we chose neopterin and cortisol, and determined their levels with respect to the genotype. In that context, we also assessed the possibility of using neopterin as a new, nontraditional marker of stress reaction in pigs.

\section{Methods}

\section{Selection of experimental animals and experimental conditions}

The experiment was conducted on slaughter pigs (Large White $\mathrm{x}$ Landrace) with an average weight of $110 \pm 18 \mathrm{~kg}$. During terminal stage of production the animals were housed on solid concrete floors and fed the A3 feeding mixture. They were subjected to genotyping based on the ryr-1 gene. A total of 10 pigs with genotype $\mathrm{Nn}$ (heterozygotes) and 15 pigs with genotype NN (homozygous halothane-negative) were selected. Their transfer to the slaughterhouse took $30 \mathrm{~min}$. The blood samples were taken before the shipment and immediately after animal's arrival in slaughterhouse. The animals were transported under conditions complying with law No. 246/1992 for protection of animals against cruelty, and regulation No. 193/2004 for protection of animals during transportation, as published in the Register of Laws and Regulations.

\section{Sample treatment before neopterin determination}

After coagulation the blood samples were centrifuged at $3000 \mathrm{xg}$ for $15 \mathrm{~min}$, the serum thus obtained was frozen and kept at the temperature of $-18^{\circ} \mathrm{C}$ until final analysis. Prior to the actual analysis, the serum samples were properly thawed at room temperature and carefully mixed by gentle turning.

A modified HPLC method according to Carru et al. (2004) was used to determine the quantity of neopterin in the serum. For protein removal, $100 \mu \mathrm{l} 20 \%$ trichloroacetic acid were added to $500 \mu \mathrm{l}$ of serum and vortexed for $10 \mathrm{~s}$. After $10 \mathrm{~min}$ the sample were centrifuged at $3000 \mathrm{xg}$ for $15 \mathrm{~min}$.

\section{HPLC analysis of neopterin}

The supernatant was filtered through a $0.45 \mu \mathrm{m}$ nylon membrane filter, and $50 \mu \mathrm{l}$ of the sample were injected into the HPLC system. The detection was accomplished by means of Alliance 2695 chromatographic system (Waters, USA) with an FD 2475 
Table 1. Neopterin and cortisol serum levels before (control) and after transporting the experimental animals to slaughterhouse (shipped) in relation to porcine genotype.

\begin{tabular}{|c|c|c|c|c|c|}
\hline \multirow[b]{2}{*}{ Halothane genotype } & \multirow[b]{2}{*}{ (n) } & \multicolumn{2}{|c|}{ Neopterin (nmol/l) } & \multicolumn{2}{|l|}{ Cortisol (nmol/l) } \\
\hline & & Control & Shipped & Control & Shipped \\
\hline$N N$ & 15 & $5.22 \pm 1.2$ & $8.11 \pm 1.6 * *$ & $272.56 \pm 72.0$ & $350.42 \pm 90.6 * *$ \\
\hline$N n$ & 10 & $5.16 \pm 1.0$ & $8.46 \pm 1.6 * *$ & $274.99 \pm 60.1$ & $363.58 \pm 80.3 * *$ \\
\hline$N N+N n$ & 25 & $5.20 \pm 1.1$ & $8.25 \pm 1.6 * *$ & $273.54 \pm 66.17$ & $355.69 \pm 85.1 * *$ \\
\hline
\end{tabular}

Data are mean value \pm S.D. $* *$ significantly different $(p<0.01)$ from control.

fluorescent detector (Waters, USA). The column used was Zorbax Eclipse XDB-C18 $(150 \times 4.6 \mathrm{~mm}, 5 \mu \mathrm{m}$; Agilent, USA). The analysis was done in an isocratic order, using water/acetonitrile $(97 / 3, \mathrm{v} / \mathrm{v})$ as the mobile phase, all materials being of HPLC-grade purity. The mobile phase flow rate was $0.9 \mathrm{ml} \cdot \mathrm{min}^{-1}$, column temperature $35{ }^{\circ} \mathrm{C}$. The detection was performed at the wavelengths selected as $\lambda_{\mathrm{ex}}=353 \mathrm{~nm}$ and $\lambda_{\mathrm{em}}=438 \mathrm{~nm}$.

\section{Sample treatment before cortisol determination}

SPEC $\mathrm{C}_{18}$ AR cartridges of $3 \mathrm{ml}$ with $15 \mathrm{mg}$ solid-phase mass per column (Varian, USA) were used. $500 \mu \mathrm{l}$ of the sample containing the internal standard (19-nortestosterone, final concentration $2 \mathrm{ng} / \mu \mathrm{l}$ ) was allowed to pass through a preconditioned cartridge (500 $\mu \mathrm{l}$ methanol and $500 \mu \mathrm{l}$ water). The cartridge was then washed with $500 \mu \mathrm{l}$ acetone/water $(10 / 90, \mathrm{v} / \mathrm{v})$ and after drying the cartridge for $5 \mathrm{~min}$ the analyte was eluted with $1 \mathrm{ml}$ acetonitrile.

\section{HPLC analysis of cortisol}

The sample volume injected into the HPLC system was $20 \mu \mathrm{l}$. Cortisol was separated by an isocratic elution method ( $65 \%$ acetonitril, $35 \%$ water $\mathrm{v} / \mathrm{v})$ on the Zorbax Eclipse XDB-C18 column $(150 \times 4.6 \mathrm{~mm}, 5 \mu \mathrm{m}$; Agilent, USA). The mobile phase flow rate was $1 \mathrm{ml} / \mathrm{min}$, column temperature was $30{ }^{\circ} \mathrm{C}$, and UV detection was done at $245 \mathrm{~nm}$.

\section{Validation parameters}

Peak identification was based on comparing the retention time with the standards for the studied biomolecules. The linearity for neopterin was measured in the concentration range of $0.6-250 \mathrm{ng} / \mathrm{ml}(\mathrm{y}=9369.5 \mathrm{x}$ $\left.+2111.4 ; r^{2}=0.999\right)$ and for cortisol in the range of 0.01$20 \mu \mathrm{g} / \mathrm{ml}\left(\mathrm{y}=23.716 \mathrm{x}+538.87 ; \mathrm{r}^{2}=0.999\right)$. Neopterin detection limit was $0.5 \mathrm{ng} / \mathrm{ml}(3 \mathrm{~S} / \mathrm{N})$, determination limit $1.49 \mathrm{ng} / \mathrm{ml}(10 \mathrm{~S} / \mathrm{N})$, method yield $81 \%$, repeatability $5.6 \%$ (RSD). Detection limit for cortisol was $20 \mathrm{ng} / \mathrm{ml}$ (3 $\mathrm{S} / \mathrm{N})$, determination limit was $64.6 \mathrm{ng} / \mathrm{ml}(10 \mathrm{~S} / \mathrm{N})$, and the method yield amounted to $91 \%$, repeatability $4.8 \%$ (RSD).

\section{Statistical evaluation}

The results were processed by STAT Plus statistic program (Matoušková et al. 1992). The data were tested for normal distribution using KolmogorovSmirnov test. The comparison of analytes (neopterin, cortisol) concentrations in the pig before and after transfer was performed using paired t-test. The comparison of two genotype (NN and Nn) was performed using unpaired t-test. $\mathrm{P}<0.01$ value was considered statistically significant for all analyses.

\section{Results}

Neopterin level in the control serum of animals before the slaughterhouse transfer was $5.6 \pm 1.65 \mathrm{nmol} / 1$ $(n=25)$. A 30-min transportation of the experimental animals $(n=25)$ to the slaughter facility resulted in a significant increase $(\mathrm{p}<0.01)$ in neopterin concentration in the serum $(8.25 \pm 1.60 \mathrm{nmol} / \mathrm{l}$ (Table 1). However, no statistically significant difference in neopterin concentration between the pigs with genotype $\mathrm{NN}$ and those with genotype Nn was observed (Fig. 1).

We have also found a statistically significant increase $(p<0.01)$ of cortisol concentration in the transported animals' serum as compared to the controls for both genotypes (Fig. 2). However, as in the previous case, there was no statistically significant differences between the animal group with genotype $\mathrm{NN}$ and that one with genotype Nn (Table 1). 


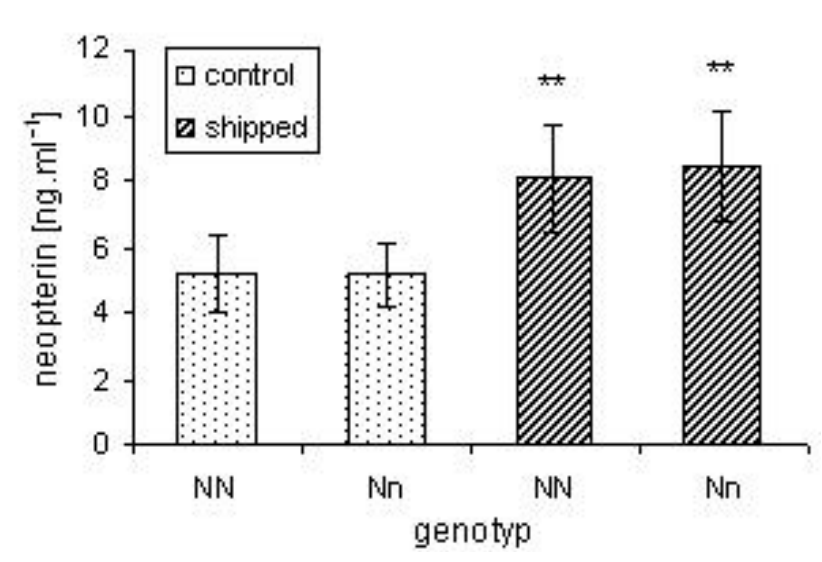

Fig. 1. Concentration of neopterin (mean value \pm S.D.) in pig serum $24 \mathrm{~h}$ before (control) and after a 30-min long transport (shipped) in relation to porcine genotype $(* * \mathrm{p}<0.01)$.

\section{Discussion}

The process of transportation influences the nervous, endocrine and immune systems of the animals, ultimately causing the emergence of a whole spectrum of active biomolecules. In general, so-called stress hormones, glucocorticoids and catecholamines are released while the immune system is also affected (Elenkov and Chrousos 1999, Moynihan 2003).

This study has shown that in the course of a 30-min transfer to slaughterhouse, cortisol production increases relative to controls irrespective of the experimental animals' genotype. Similar conclusions could be drawn from the work of Yoshioka et al. (2004), where elevated cortisol levels were observed in all experimental animals regardless of the $\mathrm{Nn}$ and $\mathrm{NN}$ genotypes. Likewise, Gispert et al. (2000) and Nyberg et al. (1988) did not demonstrate a genotype effect on cortisol levels in pigs. However, under different housing conditions, higher cortisol levels were observed in pigs with genotype NN than in those with genotype Nn (Siard et al. 2003). Geers et al. (1994) noted a posttransportation decline of cortisol level in pigs with genotype $\mathrm{NN}$ and $\mathrm{Nn}$. No significant change in the cortisol level occurred in the animals with genotype nn. It could be argued that the different genotypes in pigs do not have a clear-cut impact on cortisol levels in body fluids under various stressful situations.

In general terms, it is possible to postulate on the basis of our results that transportation stress has an unequivocally stimulating effect on cortisol concentrations in the serum. These conclusions agree with the results of other autors (McGlone et al. 1993, Geers et al. 1994, Nwe et al. 1996, Geverink et al. 1998,

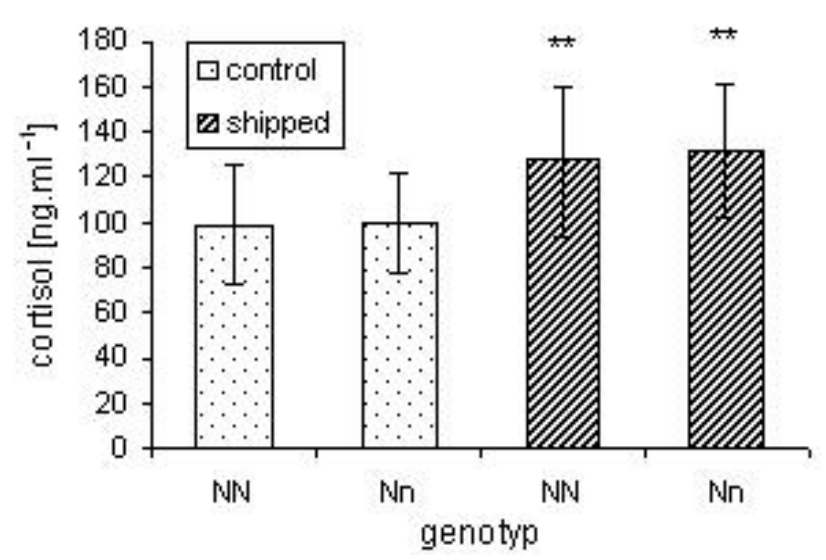

Fig. 2. Concentration of cortisol (mean value \pm S.D.) in pig serum $24 \mathrm{~h}$ before (control) and after a 30-min long transport (shipped) in relation to porcine genotype $(* * p<0.01)$.

Pérez et al. 2002).

The second biomolecule monitored in the present study was neopterin. Our results demonstrate that a short-term stress does affect the neopterin level in the serum. After 30 min transportation, there was an elevated level of neopterin. However, it is impossible to compare our results with any other report from veterinary medicine dealing with the effects of stress on the production of neopterin. This is because few papers were published on neopterin determination in pigs. The work of Schrodl et al. (1998) is concerned with the influence of bacterial infection (Haemophilus parasuis) on neopterin levels in the pig serum. They noted a drop of the neopterin level in infected animals. Amann et al. (2001) also studied the possibility of utilizing the measurements of neopterin in porcine serum for monitoring cardiac arrests. However, their results imply that neopterin concentration is not a good indicator of the immune system activation in that particular situation.

It is a generally accepted that stress affects the immune system. Glucocorticoids suppress the production of proinflammatory cytokines, TNF- $\alpha$, INF- $\gamma$ and interleukin-2, but on the other hand, together with catecholamines, they stimulate the production of cytokines during the type $\mathrm{T}$ helper 2 immune reaction (Elenkov and Chrousos 1999). However, in the study of McGlone et al. (1993), the activity of natural killer (NK) cells in pigs stressed by transportation did not decline, in spite of a documented increase of cortisol concentration in the experimental group. Salak-Johnson et al. (1996) reported that glucocorticoids are not the direct cytotoxicity-suppressing agents in NK cells at physiological or moderately elevated levels. A question presents itself regarding the possibility of utilizing 
neopterin as a marker of immune system activation in periods of acute stress. Pteridines are functionally closely related to the immune system. INF- $\gamma$, which is produced and secreted by activated T cells and NK cells, stimulates GTP cyclohydroxylase activity, resulting in synthesis of pteridines neopterin and tetrahydrobiopterin, which is essential cofactor of the aromatic amino acid hydroxylase (i.e. phenylalanine hydroxylase, tryptophane hydroxylase, tyrosine hydroxylase) and NO synthase (Thöny et al. 2000).

Neopterin is an established, validated marker of the activation of cell-mediated immunity in human medicine. Furthermore, neopterin concentrations reflect the level of the oxidative stress caused by activation of the immune system (Berdowska and Zwirska-Korczala 2001). Neopterin and biopterin are not metabolized within the organism and their biological half-time depends on excretion by the kidney (Fuchs and Wachter 1998, Bjelakovič et al. 2004).

The elevated neopterin levels in the serum of transported pigs, as observed in our work, indicate that short-term transportation is accompanied by activation of immune system cells and production of proinflammatory cytokine within the NK cells.

We conclude that neopterin may be a useful biochemical indicator of immune system stimulation by short-term stress. Our study confirmed that in the process of transporting animals for slaughter, the axis consisting of hypothalamus-hypophysis-adrenal gland becomes activated and, in a short time, cortisol is being produced. However, the results of our experiment did not show any relationship of the porcine stress syndrome genotype to the endocrine and immune systems of pigs.

\section{Acknowledgements}

We wish to thank the team of Applied Molecular Genetics Laboratory MZLU in Brno for genotyping (Prof. Ing. Josef Dvořák, CSc.). This study received financial support from Research Grant MSM 6215712402 "Veterinary Aspects of Food Safety and Quality".

\section{References}

AMANN A, WIDNER B, RIEDER J, ANTRETTER H, HOFFMANN G, MAYR V, STROHMENGER HU, FUCHS D: Monitoring of immune activation using biochemical changes in porcine model of cardiac arrest. Mediators Inflamm 10: 343-346, 2001.

BAIER-BITTERLICH G, FUCHS D, MURR CH, REIBNEGGER G, WERNER-FELMAYER G, SGONC R, BÖCK G, DIERICH MP, WACHTER H: Effect of neopterin and 7,8-dihydroneopterin on tumor necrosis factor- $\alpha$ induced programmed cell death. FEBS Lett 364: 234-238, 1995.

BERDOWSKA A, ZWIRSKA-KORCZALA K: Neopterin measurement in clinical diagnosis. J Clin Pharm Ther 26: 319-329, 2001.

BJELAKOVIČ G, JEVTOVIČ-STOIMENOV T, BJELAKOVIČ B, STOJANOVIČ I: Biochemical functions and clinical importance of unconjugated pteridines. Facta Universitatis Med Biol 11: 49-54, 2004.

VON BORELL EH: The biology of stress and its application to livestock housing and transportation assessment. $J$ Anim Sci 79: E260-E267, 2001.

CARRU C, ZINELlU A, SOTGIA S, SERRA R, USAI MF, PINTUS GF, PES GM, DEIANA L: A new HPLC method for serum neopterin measurement and relationship with plasma thiols levels in healthy subjects. Biomed Chromatogr 18: 360-366, 2004.

DAŇOVÁ K: Neopterin and its clinical significance (in Czech). Lek Obz 47: 117-120, 1998.

ELENKOV IJ, CHROUSOS GP: Stress hormones, Th1/Th2 patterns, pro/anti-inflammatory cytokines and susceptibility to disease. Trends Endocrinol Metab 10: 359-368, 1999.

FUCHS D, WACHTER H: Neopterin. In: Clinical Laboratory Diagnostics, L. Thomas (eds), TH Books Verlagsgesellschaft mbH, Frankfurt, Germany, 1998.

GEERS R, BLEUS E, VANSCHIE T, VILLE H, GERARD H, JANSSENS S, NACKAERTS G, DECUYPERE E, JOURQUIN J,: Transport of pigs different with respect to the halothane gene - stress assessment. J Anim Sci 72: 2552-2558, 1994.

GEVERINK NA, BÜHNEMANN A, VAN DE BURGWAL JA, LAMBOOIJ E, BLOKHUIS HJ, WIEGANT VM: Responses of slaughter pigs to transport and lairage sounds. Physiol Behav 63, 667-673, 1998. 
GISPERT M, FAUCITANO L, OLIVER MA, GUÁRDIA MD, COLL C, SIGGENS K, HARVEY K, DIESTRE A: A survey of pre-slaughter conditions, halothane gene frequency, and carcass and meat quality in five Spanish pig commercial abattoirs. Meat Sci 55: 97-106, 2000.

HOFFMANN G, WIRLEITNER B, FUCHS D: Potential role of immune system activation-associated production of neopterin derivatives in humans. Inflamm Res 52: 313-321, 2003.

MATOUŠKOVÁ O, CHALUPA J, CÍGLER M, HRUŠKA K: STAT-Plus - Manual, version 1.01 (in Czech). Veterinary Research Institute, Brno, 1992, 168 pp.

MCGLONE JJ, SALAK JL, LUMPKIN EA, NICHOLSON RI, GIBSON M, NORMAN RL: Shipping stress and social status effect on pig performance, plasma cortisol, natural killer cell activity, and leukocyte numbers. J Anim Sci 71: 888-896, 1993.

MITAKA CH: Clinical laboratory differentiation of infectious versus non-infectious systemic inflammatory response syndrome. Clin Chim Acta 351: 17-29, 2005.

MÖSTL E, PALME R: Hormones as indicators of stress. Domest Anim Endocrinol 23: 67-74, 2002.

MOYNIHAN JA: Mechanisms of stress-induced modulation of immunity. Brain Behav Immun 17 (Suppl 1): 11-16, 2003.

MYERS MJ, FARRELL DE, PALMER DC, POST LO: Inflammatory mediator production in swine following endotoxin challenge with or without co-administration of dexamethasone. Int Immunopharmacol 3: 571-579, 2003.

NYBERG L, LUNDSTROM K, EDFORS-LILJA I, RUNDGREN M: Effects of transport stress on concentrations of cortisol, corticosteroid-binding globulin and glucocorticoid receptors in pigs with different halothane genotypes. J Anim Sci 66: 1201-1211, 1988.

NWE TM, HORI E, MANDA M, WATANABE S: Significance of catecholamines and cortisol levels in blood during transportation stress in goats. Small Rumin Res 20: 129-135, 1996.

OETTL K, WIRLEITNER B, BAIER-BITTERLICH G, GRAMMER T, FUCHS D, REIBNEGGER G: Formation of oxygen radicals in solutions of 7,8-dihydroneopterin. Biochem Biophys Res Commun 264: 262-267, 1999.

PÉREZ MP, PALACIO J, SANTOLARIA MP, ACEÑA MC, CHACÓN G, VERDE MT, CALVO JH, ZARAGOZA MP, GASCÓN M, GARCÍA-BELENGUER S: Influence of lairage time on some welfare and meat quality parameters in pigs. Vet Res 33: 239-250, 2002.

RAZUMOVITCH JA, SEMENKOVA GN, FUCHS D, CHERENKEVICH SN: Influence of neopterin on the generation of reactive oxygen species in human neutrophils. FEBS Lett 549: 83-86, 2003.

SALAK-JOHNSON JL, MCGLONE JJ, NORMAN RL: In vivo glucocorticoid effects on porcine natural killer cell activity and circulating leukocytes. J Anim Sci 74: 584-592, 1996.

SCHOBERSBERGER W, HOFFMANN G, HOBISCH-HAGEN P, BÖCK G, VÖLKL H, BAIER-BITTERLICH G, WIRLEITNER B, WACHTER H, FUCHS D: Neopterin and 7,8-dihydroneopterin induce apoptosis in the rat alveolar epithelial cell line L2. FEBS Lett 397: 263-268, 1996.

SCHRODL W, KUNZE R, KRUGER M: Determination of C-reactive protein and neopterin in serum diseased and bacterially infected swine. Berl Munch Tierarztl Wschr 111: 321-325, 1998.

SIARD A, KOVAČ M, LADEWIG J, ŠTUHEC I: Relationship between MHS status and plasma cortisol concentration in individually confined pigs. Czech J Anim Sci 48: 265-270, 2003.

THÖNY B, AUERBACH G, BLAU N: Tetrahydrobiopterin biosynthesis, regeneration and functions. Biochem J 347: $1-16,2000$.

VRECKO K, STAEDTLER P, MISCHAK I, MARESCH L, REIBNEGGER G: Periodontitis and concentrations of the cellular immune activation marker neopterin in saliva and urine. Clin Chim Acta 268: 31-40, 1997.

WAPPLER F: Malignant hyperthermia. Eur J Anaesthesiol 18: 632-652, 2001.

WEISS G, FUCHS D, HAUSEN A, REIBNEGGER G, WERNER ER, WERNER-FELMAYER G, SEMENITZ E, DIERICH MP, WACHTER H: Neopterin modulates toxicity mediated by reactive oxygen and chloride species. FEBS Lett 321: 89-92, 1993. 
WERNER-FELMAYER G, BAIER-BITTERLICH G, FUCHS D, HAUSEN A, MURR CH, REIBNEGGER G, WERNER ER, WACHTER H: Detection of bacterial pyrogens on the basic of their effects on gamma interferon-mediated formation of neopterin or nitrite in cultured monocyte cell lines. Clin Diag Lab Immunol 2: 307-313, 1995.

WIDNER B, ENZINGER C, LAICH A, WIRLEITNER B, FUCHS D: Hyperhomocysteinemia, pteridines and oxidative stress. Curr Drug Metab 3: 225-232, 2002a.

WIDNER B, LAICH A, SPERNER-UNTERWEGER B, LEDOCHOWSKI M, FUCHS D: Neopterin production, tryptophan degradation, and mental depression - What is the link? Brain Behav Immun 16: 590-595, $2002 \mathrm{~b}$.

WIRLEITNER B, SCHROECKSNADEL K, WINKLER CH, FUCHS D: Neopterin in HIV-1 infection. Mol Immun 42: 183-194, 2005.

YOSHIOKA G, IMAEDA N, TORIMOTO Y, OHTANI T, HAYASHI K: Influence of transport stress on serum cortisol and thyroid hormones in pig with halothane gene. Anim Sci J 75: 451-456, 2004.

Law No. 246/1992 for protection of animals against cruelty. Register of Laws and Regulations, 1992, part 50, pp. 12841290

Regulation No. 193/2004 for protection of animals during transportation. Register of Laws and Regulations, 2004, part 64, pp. 2920-2936

\section{Corresponding author}

Klára Breineková, Department of Milk Hygiene and Technology, University of Veterinary and Pharmaceutical Sciences, Palackého 1-3, 61242 Brno, Czech Republic. E-mail: Klara.Breinekova@synthon.cz 